Article

\title{
Rhus coriaria L. Fruit Extract Prevents UV-A-Induced Genotoxicity and Oxidative Injury in Human Microvascular Endothelial Cells
}

\author{
Emma Nozza $^{1}{ }^{\oplus}$, Gloria Melzi ${ }^{1}{ }^{1}$, Laura Marabini $^{2}{ }^{\circledR}$, Marina Marinovich ${ }^{1}$, Stefano Piazza ${ }^{1}$, \\ Saba Khalilpour ${ }^{3}$, Mario Dell'Agli ${ }^{1, *(1)}$ and Enrico Sangiovanni ${ }^{1}$ (i) \\ 1 Department of Pharmacological and Biomolecular Sciences (DiSFeB), Università degli Studi di Milano, \\ 20133 Milan, Italy; emma.nozza@studenti.unimi.it (E.N.); gloria.melzi@unimi.it (G.M.); \\ marina.marinovich@unimi.it (M.M.); stefano.piazza@unimi.it (S.P.); enrico.sangiovanni@unimi.it (E.S.) \\ 2 Department of Environmental Science and Policy (ESP), Università degli Studi di Milano, 20133 Milan, Italy; \\ laura.marabini@unimi.it \\ 3 Boston University School of Medicine, Arthritis Center/Rheumatology, Boston, MA 02118, USA; \\ saba.khalilpour@unimi.it \\ * Correspondence: mario.dellagli@unimi.it; Tel.: +390250318398
}

Received: 19 March 2020; Accepted: 29 March 2020; Published: 1 April 2020

\begin{abstract}
Rhus coriaria L. (sumac) is a small plant widely diffused in the Mediterranean region. Its fruit are often consumed as a spice but are also present in traditional medicine of several countries. Recently, interest in this plant has increased and many scientific works reported its beneficial effects including antioxidant and anti-inflammatory properties. Plant extracts can be successfully used against ultraviolet rays, which are able to reach and damage the human skin; however, sumac extracts were never applied to this usage. Thus, in this study, we used a macerated ethanol extract of Rhus coriaria L. dried fruit (mERC) to demonstrate its preventive role against the damage induced by ultraviolet-A rays (UV-A) on microvascular endothelial cells (HMEC-1). In vitro effects of the extract pre-treatment and UV-A exposure were evaluated in detail. The antioxidant capacity was assessed by reactive oxygen species (ROS) formation and cellular antioxidant activity measurement. Genoprotective effects of mERC were investigated as well. Our findings indicate that the extract acts as a cell cycle inhibitor or apoptosis inducer, according to the level of damage. The present work provides new insights into the usage of Rhus coriaria extracts against skin injuries.
\end{abstract}

Keywords: Rhus coriaria L.; sumac; UV-A; antioxidant; genotoxicity; microvascular endothelial cells; HMEC-1

\section{Introduction}

Since ancient times, natural products have been used as remedies for the treatment of several pathological conditions, including skin diseases [1].

Rhus coriaria L., commonly called sumac or Sicilian sumac, is a small tree native to southern Europe, belonging to the Anacardiaceae Family. The red fruit of Rhus coriaria is used as a very popular spice in Persian countries, either in pure form or in combination with other spices, due to their sour lemon taste. Sumac is traditionally used in Asia and Europe as food or medicinal herb for the treatment of diarrhea, hemorrhoids, and gout [2,3].

Phytochemical studies have shown that fruit are rich in hydrolysable tannins, mostly gallotannins, gallic acid derivatives, anthocyanins, and various organic acids such as malic and citric acids, fatty acids, vitamins, and terpenes [4-7]. 
According to the literature, Sumac fruit possess a multitude of biological activities including beneficial effects in vivo in streptozotocin-induced diabetes [8], lipid-lowering effects in hypercholesterolemic rats [9], cardioprotective effects in hyperlipidemic patients [10,11], prevention of necrotizing enterocolitis [12], neuroprotective effects in a mouse model of ischemic optic neuropathy [13,14] and an in vitro model of retinal degeneration [15]. Moreover, Chakraborty A. and colleagues showed in vivo scavenging effects of sumac and inhibition of DNA bases oxidation, also following $\gamma$-irradiation [16]. Rhus coriaria L. extracts were also used on diabetic patients, where notably decreased serum glucose levels [11]. Recently, our group demonstrated the beneficial effect of Rhus coriaria $\mathrm{L}$. fruit extracts as preventive agents in the treatment of keratinocytes inflammation through their inhibition of skin pro-inflammatory mediators, including IL-8, MMP-9, ICAM-1, and VEGF [6].

Botanicals are more and more used in the treatment of skin disorders for their ability to efficiently counteract the damage induced by environmental agents, such as sunlight [17-19]. Ultraviolet rays are the most dangerous component of the solar radiation, both UV-A and UV-B are able to act on epidermal cells, damaging them, and UV-A can also penetrate into the dermis [20].

UV-A (320-400 nm) are the most abundant fraction of ultraviolet rays to reach the Earth's surface due to their ability to pass through the atmosphere, the ozone layer, and through clouds and glass, leading also to a relevant indoor exposure [21]. Since 2009, UV-A rays are included in class I carcinogenic substances from IARC [22]. UV-A exposure can induce both acute and chronic effects: firstly, erythema, immediate pigment darkening (IPD) and persistent pigment darkening (PPD), then, photoaging and carcinogenesis [23].

UV-A rays are responsible for damaging the whole dermic layer, altering collagen, elastin, and activating metalloproteases (MMPs), all leading to tissue photoaging [24-26]. Furthermore, their action on fibroblasts and even more on endothelial cells can determinate another negative effect on the epidermis $[18,27]$.

At molecular level, UV-A rays mediate the formation of reactive oxygen species (ROS), alter proteins and lipid structures, damage DNA, and promote inflammation processes. UV-A induced damage is mainly oxidative, and this is particularly relevant in endothelial cells, whose alteration could compromise the whole function of vessels [28].

To correctly mimic the complex situation of dermal vessels in vitro, an immortalized human microvascular endothelial cell line (HMEC-1) was chosen; these cells are commonly used as in vitro model of the skin microvascular endothelium [29]. The reliability of this model as a tool for the study of UV-A irradiation has been previously reported [30].

This work investigates the photoprotective effect of a macerated ethanolic extract of Rhus coriaria $\mathrm{L}$. dried fruit (mERC) against UV-A damage and the genoprotective effects in microvascular endothelial cells. Damage and protection were examined through evaluation of the effects on oxidation, genotoxicity, and cytotoxicity.

\section{Materials and Methods}

\subsection{Rhus coriaria L. Extract Preparation and Characterization}

Rhus coriaria fruit were purchased in the Taleghan region (Iran), and plant material was authenticated by the Herbarium Unit, School of Biological Sciences. For extract preparation, dried fruit was ground, and $5 \mathrm{~g}$ was extracted in pure ethanol $(50 \mathrm{~mL})$ at room temperature (RT) for $48 \mathrm{~h}$ under stirring, as previously reported [6]. The mixture was filtered, taken to dryness, and freeze dried, obtaining Rhus coriaria L. macerated extract (mERC). The extraction yield was 15.2\%. Phytochemical characterization by HPLC-UV-DAD analysis showed the presence of gallotannin derivatives and flavonoids, including anthocyanins (cyanidin derivatives), as reported in [6]. 


\subsection{Cell Culture}

The HMEC-1 cell line (Centers for Disease Control and Prevention, Atlanta, GA, USA) was kindly gifted by Prof. Nicoletta Basilico, Dipartimento di Scienze Biomediche, Chirurgiche e Odontoiatriche, Università degli Studi di Milano (Italy). Cells were grown in MCDB 131 medium (Sigma Aldrich) plus $1 \%$ penicillin/streptomycin, $10 \%$ fetal bovine serum (FBS), $20 \mathrm{mM} \mathrm{HEPES} \mathrm{buffer,} 1 \mu \mathrm{g} / \mathrm{mL}$ hydrocortisone and $10 \mathrm{ng} / \mathrm{mL}$ epidermal growth factor (EGF) [31]. Cells were maintained at $37{ }^{\circ} \mathrm{C}$ in a $5 \% \mathrm{CO}_{2}$ atmosphere and passaged every $3 / 4$ days. For experiments, where not differently stated, cells' growth lasted $48 \mathrm{~h}$.

\subsection{Rhus coriaria L. Extract Treatment}

Cells were incubated for $1 \mathrm{~h}$ with mERC diluted in a serum-free medium at the final concentrations of 10 or $25 \mu \mathrm{g} / \mathrm{mL}$ (E10, E25). The incubation was performed right before UV-A exposure.

\subsection{UV-A Radiation Treatment}

UV-A treatments were performed using a four-lamp UV-A system (TRIWOOD 31/36, Helios Italquartz). During UV-A exposure, cells were maintained in a thin layer of phosphate buffered saline (PBS; $2 \mathrm{~mL}$ in $60 \mathrm{~mm}$ Petri dishes, $1 \mathrm{~mL}$ in $35 \mathrm{~mm}$ Petri dishes, $500 \mu \mathrm{L}$ in 24-well plates, $100 \mu \mathrm{L}$ in 96-well plates) and their supports encircled by ice, to avoid external interferences [32]. Moreover, control samples were maintained in PBS at RT for the same time. In this study, four different UV-A doses, 10, 15,20 , and $25 \mathrm{~J} / \mathrm{cm}^{2}$ (T10, T15, T20, T25) were tested. Unless different indications, experiments were performed directly after UV-A treatment.

\subsection{ROS Quantification and Lowry Protein Assay}

To evaluate the production of intracellular ROS, a fluorescence spectrometry protocol combined with Lowry protein quantification was applied. $1 \times 10^{4}$ cells were seeded on a 96-well black plate; after treatment, cells were diluted 1:2000 in medium and incubated for $30 \mathrm{~min}$ with $50 \mathrm{mM}$ fluorescent probe (DCFH-DA, 2', , $7^{\prime}$-dichlorofluorescein diacetate, Sigma Aldrich). The probe binds cytoplasmatic ROS and emits fluorescence (Figure S1), which is detected with a spectrofluorometer at $495 \mathrm{~nm}$ wavelength. Fluorescence values were normalized on the protein content of each sample, after the quantification

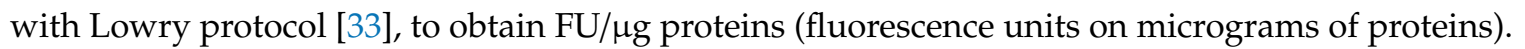

\subsection{Quantification of the Total Antioxidant Activity}

The total antioxidant activity was evaluated using a colorimetric reaction kit (MAK 187, Sigma, Milan, Italy). The assay was performed following the manufacturer's instructions on cell lysate. Briefly, HMEC-1 were seeded on $60 \mathrm{~mm}$ Petri dishes at a density of $2.15 \times 10^{4} \mathrm{cell} / \mathrm{cm}^{2}$ and grown for $72 \mathrm{~h}$, before treatment. Then, cells were scraped, collected, and mechanically lysed using a potter. Absorbance values were compared with the Trolox standard curve and expressed as Trolox equivalents normalized on cell viability (MTT).

\subsection{Alkaline Comet Assay}

The alkaline Comet assay is a well-known single cell gel electrophoresis (SCGE) protocol for evaluating DNA damage. It was performed immediately or $24 \mathrm{~h}$ after treatment, on cells seeded on $35 \mathrm{~mm}$ Petri dishes $\left(1.5 \times 10^{4} \mathrm{cell} / \mathrm{cm}^{2}\right.$ density). To perform the experiments, cells were detached using a trypsin-EDTA solution ( $0.05 \%$, Sigma Aldrich) and seeded on agarose-coated slides; to create an "agarose sandwich" another layer was spread and left to cool. Later, slides were soaked in a lysis solution (10\% DMSO, 1\% Triton X-100, 89\% Stock solution: $2.5 \mathrm{M} \mathrm{NaCl}, 250 \mathrm{mM} \mathrm{NaOH}, 100 \mathrm{mM}$ $\mathrm{Na}_{2}$ EDTA, $10 \mathrm{mM}$ Tris in water; Sigma Aldrich) for $30 \mathrm{~min}$ at $4^{\circ} \mathrm{C}$. Subsequently, slides were neutralized (0.4 M Tris in water) and kept for $30 \mathrm{~min}$ in stabilization inside an electrophoresis system with an alkaline buffer ( $300 \mathrm{mM} \mathrm{NaOH}, 1 \mathrm{mM} \mathrm{Na} 2$ EDTA in water), for DNA unwinding. At the end of the stabilization, 
the electrophoretic run was performed for $30 \mathrm{~min}$, at $300 \mathrm{~mA}$ and $25 \mathrm{~V}$. Slides were neutralized again and colored with propidium iodide to be read in fluorescence microscopy (40× oil obj., Figure S2). An amount of 100 cells/sample was analyzed using software (TriTek CometScore ${ }^{\mathrm{TM}}$ ).

\subsection{Modified Comet Assay}

A modified Comet assay protocol was used to identify the different kind of DNA damage [34]. The alkaline Comet assay was performed with some variations: the $\mathrm{pH}$ of the alkaline buffer was set at 12.1; after the lysis, slides were incubated for $45 \mathrm{~min}$ at $37^{\circ} \mathrm{C}$ with $50 \mu \mathrm{L}$ of the diluted enzymes: $\mathrm{T} 4$ PDG, ENDO III, FPG (New England BioLabs ${ }^{\circledR}$ Inc., 75-77 Knowl Piece, Wilbury Wai, Hitchin, UK). Enzymes were diluted in T4 PDG Reaction buffer to reach final concentrations of $10 \mathrm{U} / \mathrm{mL}$ for T4 PDG and FPG, $14 \mathrm{U} / \mathrm{mL}$ for ENDO III, according to manufacturer's instructions.

\subsection{Quantification of $\gamma-H 2 A X$ and Micronuclei Percentage}

The evaluation of DNA double strand break (DSB) was conducted through immunofluorescence, quantifying the phosphorylated form of the H2AX histone $(\gamma-\mathrm{H} 2 \mathrm{AX}) .3 \times 10^{4} \mathrm{cells} / \mathrm{cm}^{2}$ were seeded on round glass slides $(12 \mathrm{~mm})$. After treatment, cells were fixed with iced methanol and washed with PBS, then incubated, first with a permeabilizing solution (0.5\% Triton X-100 in PBS), and later with a 3\% PBS/BSA solution for $1 \mathrm{~h}$. Subsequently, cells were incubated overnight at $4^{\circ} \mathrm{C}$ with a primary antibody (Histone H2AX.XS139ph antibody, Active Motif) that binds the Ser139 residue on the $\gamma$-H2AX histone. The day after, slides were washed and incubated for one hour with the secondary antibody (AlexaFluor 488 Goat anti-rabbit IgG H+L, Immunological Sciences). Antibodies were diluted according to the manufacturer's instructions. Then, cells were washed again, and slides mounted using $10 \mu \mathrm{L}$ of DAPI (VectaShield, Vector). The reading was performed in fluorescence microscopy (100X oil obj.) using FITC and DAPI filters; 100 cells/sample were analysed and divided into three classes of damage: $0-5$, $6-10,>10$ foci. From the same samples was possible to count 1000 cells each and identify micronuclei, following Fenech's criteria [35].

\subsection{Evaluation of Apoptosis}

To evaluate the percentage of dead cells a flow cytometry protocol based on Annexin $V$ property of binding exposed phosphatidylserine (PS) in apoptotic cells was followed; propidium iodide was used to bind necrotic cells' DNA. $3 \times 10^{4}$ cells $/ \mathrm{cm}^{2}$ were seeded on $35 \mathrm{~mm}$ Petri dishes; after treatment, cells were incubated in serum-free medium for $24 \mathrm{~h}$. At the right time, cells were detached using a trypsin-EDTA solution (0.05\%) and incubated for $15 \mathrm{~min}$ at RT with both Annexin $\mathrm{V}$ and propidium iodide, diluted in Annexin Binding Buffer (1:20 Annexin V, 1:1000 propidium iodide; ThermoFisher). After incubation, samples were read on flow cytometry, analyzing 10000 cells each (Figure S3).

\subsection{Cell Cycle Analysis}

Cell cycle analysis was conducted in flow cytometry, measuring the DNA quantity of each cell that corresponds to a different phase of the cycle. To perform the test, $3 \times 10^{4} \mathrm{cells} / \mathrm{cm}^{2}$ were seeded on $35 \mathrm{~mm}$ Petri dishes, treated, and incubated in serum-free medium for $24 \mathrm{~h}$. Cells were then detached using a trypsin-EDTA solution $(0.05 \%)$, collected and fixed with absolute ethanol overnight at $4^{\circ} \mathrm{C}$. Afterwards, cells were incubated for 40 min with a staining solution $(0.1 \%$ Triton X-100, 5\% propidium iodide, $0.5 \%$ RNase A in PBS; Sigma Aldrich). To perform the analysis (20 000 cells/sample), the solution was removed, and cells resuspended in PBS.

\subsection{Statistical Analysis}

For conducting the statistical analysis, the samples exposed only to PBS were used as controls; samples treated only with the extract gave results similar to untreated controls for every assay. 
The statistical analysis of the experimental results was performed using the statistical software GraphPad Prism 5.01 (GraphPad Software), through the One-Way ANOVA test, associated with Bonferroni's Multiple Comparison Test. For all the experiments at least three separated data were collected and shown in the graphs as mean \pm SEM; for the two Comet assays the mean of medians \pm SEM was shown.

\section{Results}

\subsection{Rhus coriaria L. Extract Decreases UV-A-induced ROS Production}

One of the most common mechanisms increased by UV-A exposure is the production of intracellular ROS, which causes damage to the main cellular structures, also comprising DNA [36]. Endothelial cells are sensible to ROS-induced injury, which is one of the mechanisms responsible for endothelial dysfunction [37].

As shown in Figure 1, the higher dose of UV-A tested $\left(20 \mathrm{~J} / \mathrm{cm}^{2}\right)$ induced a great intracellular ROS production, which was prevented by the antioxidant properties of mERC pre-treatment. mERC $(25 \mu \mathrm{g} / \mathrm{mL})$ was able to decrease ROS production to control levels.

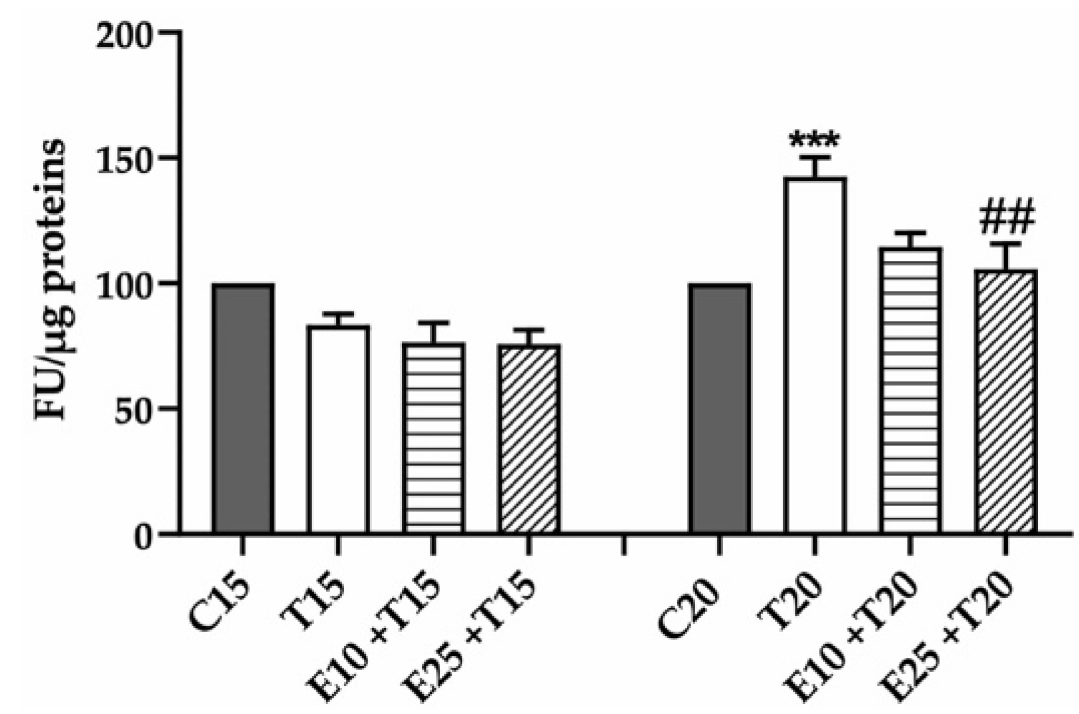

Figure 1. ROS production, expressed as Fluorescence Units on protein content $(\mu \mathrm{g})$, after mERC and UV-A treatment. HMEC-1 were treated for $1 \mathrm{~h}$ with 10 or $25 \mu \mathrm{g} / \mathrm{mL}$ of $\mathrm{mERC}$ (E10, E25) and exposed to 15 or $20 \mathrm{~J} / \mathrm{cm}^{2} \mathrm{UV}-\mathrm{A}(\mathrm{T} 15, \mathrm{~T} 20)$. Results are expressed as mean $\pm \mathrm{SEM}, n=5$. Statistical analysis: One-Way ANOVA with Bonferroni's post hoc analysis. ${ }^{* *} p<0.001$ vs. C20, \#\# $p<0.05$ vs. T20.

\subsection{Total Antioxidant Activity Reduction after UV-A Exposure in the presence of $m E R C$}

Endogenous antioxidant activity plays a major role in contrasting reactive species formation; to maintain the redox homeostasis various enzymes as superoxide dismutase (SOD) or catalase (CAT) and non-enzymatic compounds are involved [38].

UV radiation can increase ROS formation and consequently diminish the antioxidant capacity of cellular systems. Indeed, cellular antioxidant activity was measured only at $20 \mathrm{~J} / \mathrm{cm}^{2} \mathrm{UV}-\mathrm{A}$, where high release of ROS was detected (Figure 1), and the values normalized on cells' viability (Table S1). The total cellular antioxidant activity was significantly decreased in UV-A treated samples (Figure 2). 


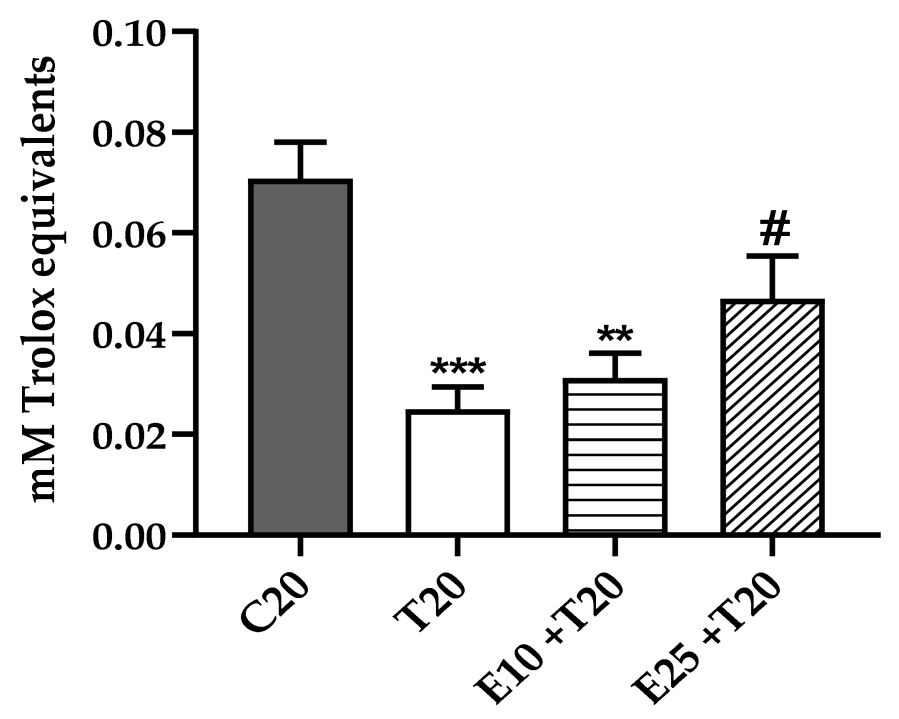

Figure 2. Effect of Rhus coriaria L. extract and UV-A rays on total cellular antioxidant activity, measured as $\mathrm{mM}$ Trolox equivalents after normalization on cell's viability. HMEC- 1 were treated for $1 \mathrm{~h}$ with 10 or $25 \mu \mathrm{g} / \mathrm{mL}$ of mERC (E10, E25) and exposed to $20 \mathrm{~J} / \mathrm{cm}^{2} \mathrm{UV}-\mathrm{A}$ (T20). Results are expressed as mean \pm SEM, $n=5$. Statistical analysis: One-Way ANOVA with Bonferroni's post hoc analysis. ${ }^{* *} p<0.05$, *** $p<0.001$ vs. C20, \# $p<0.01$ vs. T20.

The antioxidant ability of Rhus coriaria L. extracts was partially documented [39,40]; however, this study shows for the first time in endothelial cells the efficacy of mERC to counteract oxidative stress at low concentration $(25 \mu \mathrm{g} / \mathrm{mL}$, Figure 2$)$.

\subsection{Genoprotective Action of mERC Against UV-A Damage}

The beneficial effects of Rhus coriaria L. extracts presented in the literature are mainly focused on their antioxidant properties, and little is known about their genoprotective potential.

UV-A radiation has to be considered a remarkable DNA damage inducer that could be prevented by mERC pre-treatment.

\subsubsection{Evaluation of DNA Damage Through Alkaline Comet Assay}

Alkaline Comet assay highlights the presence of different kind of DNA damages, as single strand break (SSB), double strand break (DSB) or alkali-labile sites (ALS), measuring DNA fragmentation through different parameters: \% DNA in Tail, Tail length and most importantly Tail moment, which correlates with the other two parameters.

All parameters considered in the Comet assay (Figure 3) showed a significant increase of DNA damage after UV-A exposure, which was genotoxic in endothelial cells at 15 and $20 \mathrm{~J} / \mathrm{cm}^{2}$.

mERC's pre-treatment allowed a decreasing trend of genotoxicity at all UV-A doses, but a significant damage reduction was observable only at $20 \mathrm{~J} / \mathrm{cm}^{2}$ of UV-A irradiation, especially on Tail length and Tail moment parameters (Figure 3b,c). The extract was effective only at its higher concentration whereas, at $10 \mu \mathrm{g} / \mathrm{mL}$, no differences from UV treated samples were showed (data not shown). 


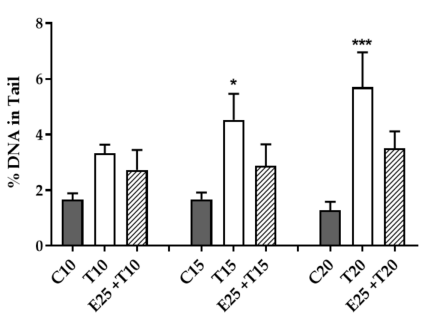

(a)

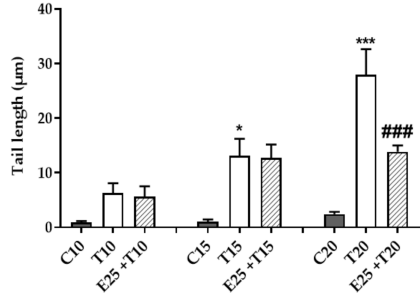

(b)

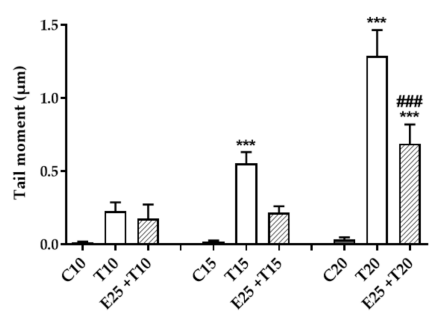

(c)

Figure 3. Effect of Rhus coriaria L. and UV-A rays on genotoxicity. Alkaline Comet assay evaluated DNA damage through (a) \%DNA in Tail, (b) Tail length and (c) Tail moment (\%DNA in Tail* Tail length). HMEC-1 cells were treated for $1 \mathrm{~h}$ with $25 \mu \mathrm{g} / \mathrm{mL}$ of mERC (E25) and exposed to 10, 15 or $20 \mathrm{~J} / \mathrm{cm}^{2} \mathrm{UV}-\mathrm{A}(\mathrm{T} 10, \mathrm{~T} 15, \mathrm{~T} 20)$. Results are expressed as mean of medians $\pm \mathrm{SEM}, n=6$. Statistical analysis: One-Way ANOVA with Bonferroni's post hoc analysis. ${ }^{*} p<0.05,{ }^{* * *} p<0.001$ vs. C PBS, $\# \#$ \# 0.001 vs. T20.

\subsubsection{Time Course of Genotoxic Damage}

The damage on DNA induced by UV-A is remarkable when detected shortly after UV-A exposition, as discussed above (Figure 3), but after $24 \mathrm{~h}$ can be reduced by the activation of cellular repair enzymes [41] or by the elimination of the most damaged cells through apoptosis [42].

Figure 4 shows a comparison between the most relevant parameter, Tail moment, evaluated immediately $(0 \mathrm{~h})$ or after $24 \mathrm{~h}$ from the UV-A exposure; $20 \mathrm{~J} / \mathrm{cm}^{2}$ was chosen as a representative dose. Indeed, the value of Tail moment after $24 \mathrm{~h}$ was significantly decreased when compared to time zero (0 h) (Figure 4).

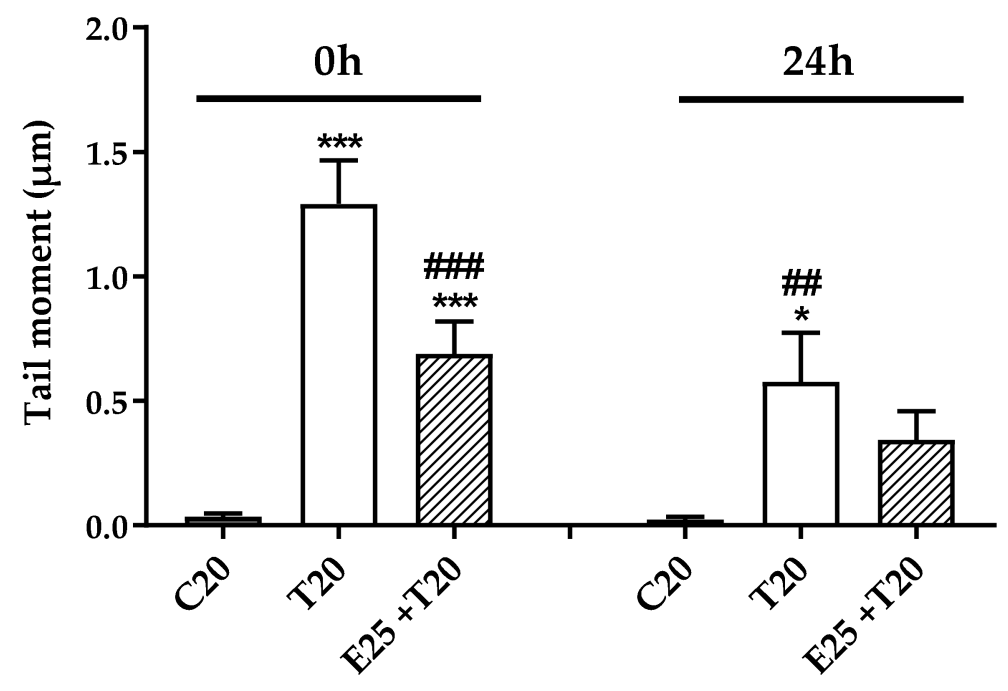

Figure 4. Comparison between Alkaline Comet assay performed after 0 and $24 \mathrm{~h}$ from UV-A exposure, expressed as Tail moment. HMEC-1 cells were treated for $1 \mathrm{~h}$ with the extract $(25 \mu \mathrm{g} / \mathrm{mL}, \mathrm{E} 25)$ and exposed to $20 \mathrm{~J} / \mathrm{cm}^{2} \mathrm{UV}-\mathrm{A}$ (T20). Results are expressed as mean of medians $\pm \mathrm{SEM}, n=3$. Statistical analysis: One-Way ANOVA with Bonferroni's post hoc analysis. ${ }^{*} p<0.05,{ }^{* * *} p<0.001$ vs. C20, \#\# $p<0.01 \# \#$ \# $<0.001$ vs. T20 0h.

\subsubsection{DSB Quantification through $\gamma-\mathrm{H} 2 \mathrm{AX}$ Detection}

To investigate the genotoxic damage induced by UV-A and the action of $\mathrm{mERC}$, the presence of the phosphorylated form of the H2AX histone, which is indicative of an early DSB repair pathway stage [43], was tested. $\gamma-\mathrm{H} 2 \mathrm{AX}$ are visible as foci, using an immunofluorescence technique, and their number in the nucleus is indicative of the damage state of the cell. 
Cells whose nuclei contain more than 10 foci, as displayed in Figure 5, are considered heavily damaged [43]. The percentage of these cells in the whole population was significantly increased in UV-A-treated samples, from the dose of $15 \mathrm{~J} / \mathrm{cm}^{2}$.

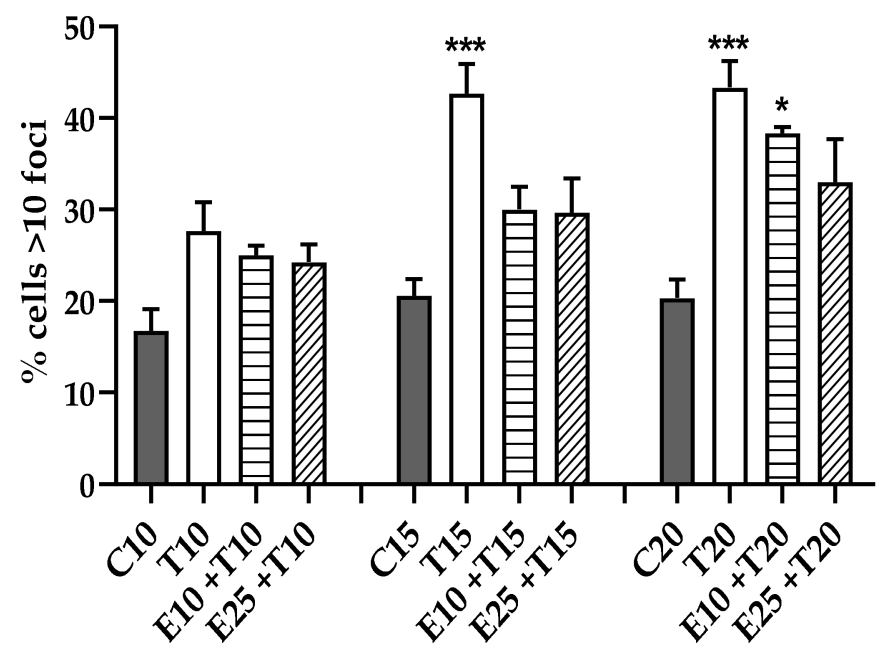

Figure 5. $\gamma-\mathrm{H} 2 \mathrm{AX}$ formation after UV-A irradiation and mERC pre-treatment. DNA DSB quantification through immunofluorescence revealing high $(>10) \gamma$-H2AX foci presence. HMEC-1 cells were treated for $1 \mathrm{~h}$ with mERC (10 or $25 \mu \mathrm{g} / \mathrm{mL}, \mathrm{E} 10$ and E25) and exposed to 10, 15, $20 \mathrm{~J} / \mathrm{cm}^{2} \mathrm{UV}-\mathrm{A}$ (T10, T15, T20). Results are expressed as mean $\pm \mathrm{SEM}, n=4$. Statistical analysis: One-Way ANOVA with Bonferroni's post hoc analysis. ${ }^{*} p<0.05^{* * *} p<0.001$ vs. C PBS.

Against this kind of damage, the extract pre-treatment resulted in a decreased number of damaged cells in the population (Figure 5). This result could be explained by the involvement of the $\gamma-\mathrm{H} 2 \mathrm{AX}$ in the mitotic process; indeed, $\gamma-\mathrm{H} 2 \mathrm{AX}$ formation in mitosis is physiological and unrelated from DNA damage [43]. In this assay, cells of each phase of the cycle were considered, making impossible to discriminate either the mitotic presence of the histone or the related damage.

\subsubsection{Chromosomal Mis-segregation as Micronuclei Formation}

The incorrect separation of chromosomes during mitosis is considered a reliable index of genomic damages [44]. This process happens to whole chromosomes or just some parts that do not migrate along with the rest of the spindle and are included in a separate membrane, originating the so-called micronuclei. Through immunofluorescence, using Fenech's criteria [35], micronuclei can be efficiently recognized, and the state of cellular DNA damage established.

UV-A irradiation induced a sharp increase of micronuclei percentage in HMEC-1 cells; this rise was significant compared to control samples, from the minimum UV dose tested $\left(10 \mathrm{~J} / \mathrm{cm}^{2}\right)$.

Pre-treatment with mERC decreased the level of damage at every dose of exposition, compared to UV-only treated samples, but the reduction was significant only at $10 \mathrm{~J} / \mathrm{cm}^{2}$ with the highest extract concentration (Figure 6). 


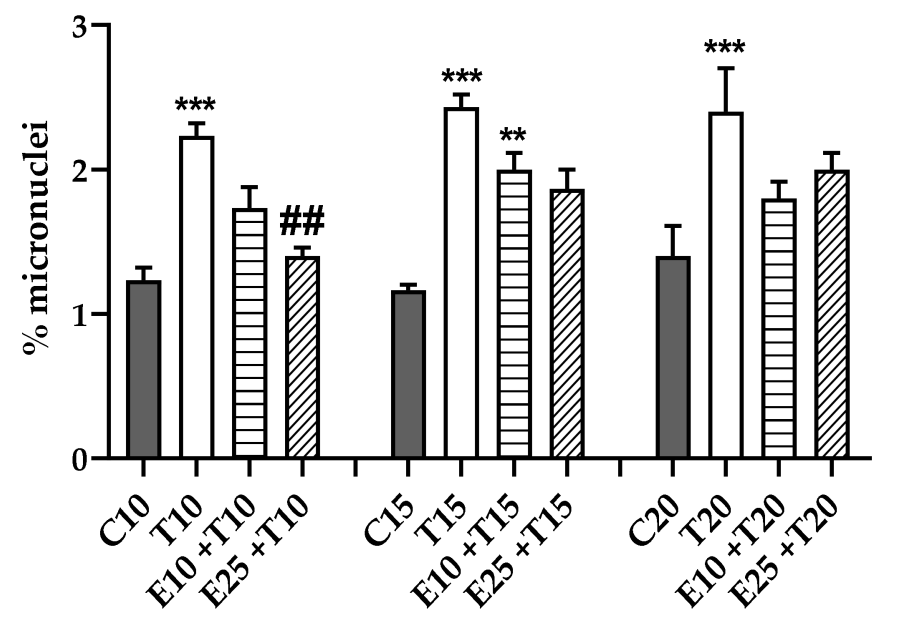

Figure 6. Effect of mERC and UV-A radiation on chromosome mis-segregation, measured as micronuclei percentage, detected by immunofluorescence. HMEC-1 cells were treated for $1 \mathrm{~h}$ with mERC (10 or $25 \mu \mathrm{g} / \mathrm{mL}, \mathrm{E} 10$ and E25) and exposed to 10, 15, $20 \mathrm{~J} / \mathrm{cm}^{2} \mathrm{UV}-\mathrm{A}$ (T10, T15, T20). Results are expressed as mean \pm SEM, $n=3$. Statistical analysis: One-Way ANOVA with Bonferroni's post hoc analysis. ** $p<0.01, * * * 0<0.001$ vs. C PBS, \#\# $p<0.01$ vs. T10.

\subsection{UV-A Damage Characterization}

To better investigate the mechanism of action of mERC against UV-A damage the main features of UV-A genotoxicity needed to be investigated. UV-A rays have been considered just inducers of oxidative damage, for their low energy and little capability of being directly absorbed by DNA [36], but recent studies demonstrated that they can also generate direct DNA damages as cyclobutane pyrimidine dimers (CPDs) [45-47]. This information provides new perspectives on UV-A damage, since the production of CPDs induces cytokines release, but also a great mutagenicity [48].

The modified Comet assay exploits specific endonucleases to recognize different kind of DNA lesions. Indirect damage is due to bases' oxidation, ENDO III identifies oxidized pyrimidines and FPG detects oxidized purines. Instead, T4 PDG is able to recognize CPDs, index of direct genotoxicity.

Figure 7 displays the amount of damage revealed by each endonuclease; they are directly correlated with the incidence of that specific lesion in the overall damage induced by UV-A on HMEC-1 cells. $20 \mathrm{~J} / \mathrm{cm}^{2}$ was chosen as a representative dose of genotoxicity. In Figure 7a is shown the presence of direct damage, using T4 PDG that appeared significant and resulted the main component of UV-A induced damage. Oxidative damage is visible with ENDO III and FPG, in Figure $7 \mathrm{~b}, \mathrm{c}$; the most prevalent indirect lesion was the oxidation of purinic bases, while pyrimidines' oxidation was almost non-detectable.

The effect of mERC's higher concentration was relevant on both direct and indirect DNA damages (Figure 7); the extract ability to significantly prevent not only oxidative, but also direct lesions is a new outcome. 


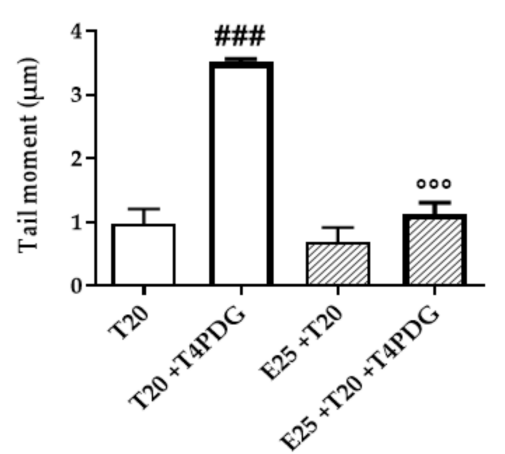

(a)

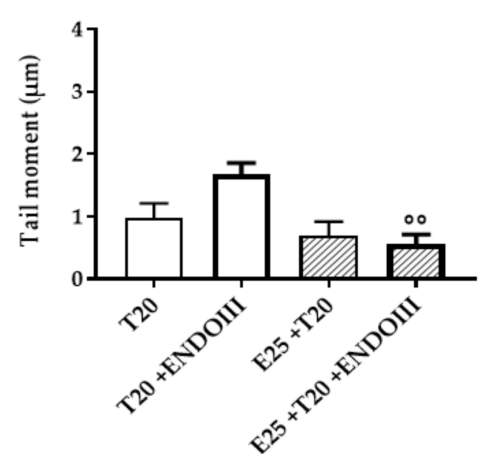

(b)

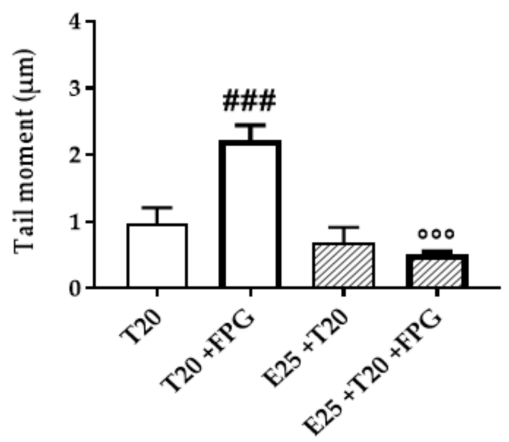

(c)

Figure 7. Characterization of genotoxic damage induced by UV-A, and mERC extract's role. Modified Comet assay measured direct DNA damage using (a) T4 PDG enzyme recognizing CPDs; indirect i.e., oxidative damage was identified by (b) ENDO III for oxidized pyrimidines or (c) FPG for oxidized purines. HMEC- 1 cells were treated for $1 \mathrm{~h}$ with mERC ( $25 \mu \mathrm{g} / \mathrm{mL}, \mathrm{E} 25)$ and exposed to $20 \mathrm{~J} / \mathrm{cm}^{2} \mathrm{UV}-\mathrm{A}$ (T20). Results are expressed as mean of medians \pm SEM, $n=3$. Statistical analysis: One-Way ANOVA with Bonferroni's post hoc analysis. \#\#\# $p<0.001$ vs. T20, ${ }^{\circ} p<0.01,{ }^{\circ \circ} p<0.001$ vs. T20+enzyme.

\subsection{Assessment of Cytotoxicity}

In the previous experiments, the great mutagenic capacity of UV-A rays in endothelial cells was clearly shown; therefore, the accumulation of subsequent damages could lead to mutations that finally result in tumor transformation. One of the main strategies to solve this problem is the activation of the apoptosis pathways.

Through flow cytometry, cellular population could be grouped in living or apoptotic cells (Figure S3). In Figure 8a, the living population shows a decreasing trend, correlated with the increase of UV-A exposition, but never significant for UV-only treated samples. The decrement was more accentuated by the extract pre-treatment, resulting in a significant decrease of living cells in samples treated with the maximum UV-A dose $\left(25 \mathrm{~J} / \mathrm{cm}^{2}\right)$. Figure $8 \mathrm{~b}$ displays the increase of apoptotic cells, resulting complementary to the living cells; apoptotic population was significantly increased only in mERC pre-treated samples, treated with high UV-A doses $\left(20-25 \mathrm{~J} / \mathrm{cm}^{2}\right)$.

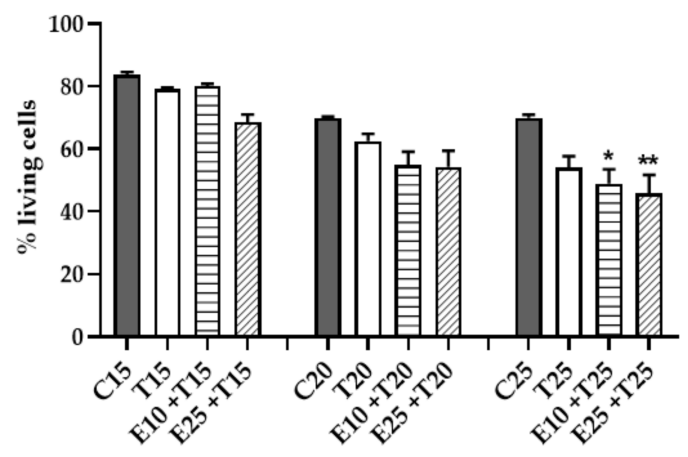

(a)

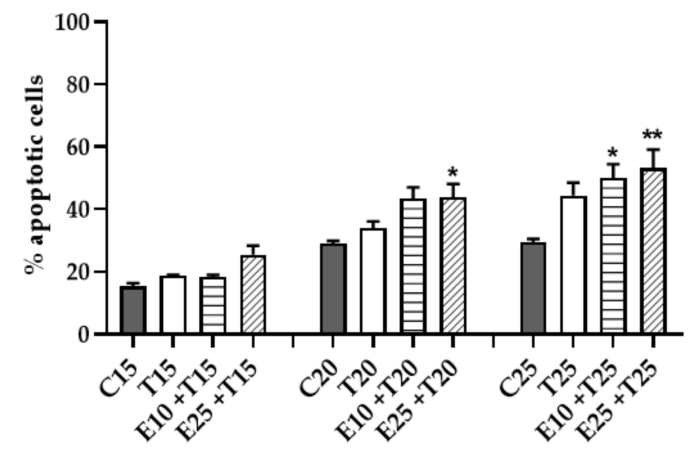

(b)

Figure 8. Cytotoxicity of UV-A rays and effects of Rhus coriaria pre-treatment, flow cytometry evaluation. Cellular population was grouped in (a) living cells and (b) apoptotic cells. HMEC-1 cells were treated for $1 \mathrm{~h}$ with 10 or $25 \mu \mathrm{g} / \mathrm{mL}$ of mERC (E10, E25) and exposed to 15, 20, $25 \mathrm{~J} / \mathrm{cm}^{2} \mathrm{UV}-\mathrm{A}$ (T15, T 20, T25). Results are expressed as mean $\pm \mathrm{SEM}, n=3$. Statistical analysis: One-Way ANOVA with Bonferroni's post hoc analysis. ${ }^{*} p<0.05,{ }^{* *} p<0.01$ vs. C PBS. 
The increase of apoptotic cells should be read as a protective mechanism by mERC's pre-treatment against the high levels of cellular damage, to avoid a possible tumor transformation. This feature of polyphenolic extracts was already stated [49].

\subsection{Role of mERC Pre-treatment and UV-A Exposure on Cell Cycle}

The induction of apoptosis is one among a variety of mechanisms implemented by cells to avoid the onset of mutations; a sudden repair pathway is the cell cycle arrest that results particularly preferred in CPDs damaged cells [50]. Flow cytometry allows evaluating both.

In Figure 9 the three most relevant phases are shown: G1, S and SubG1. G1 and S phase displayed opposed trends, relevant for the lower UV doses $\left(15-20 \mathrm{~J} / \mathrm{cm}^{2}\right)$ : a decrease in percentage of G1 cells and an increase of $S$ cells. This happened as well in mERC pre-treated samples, indicating cell cycle arrest.

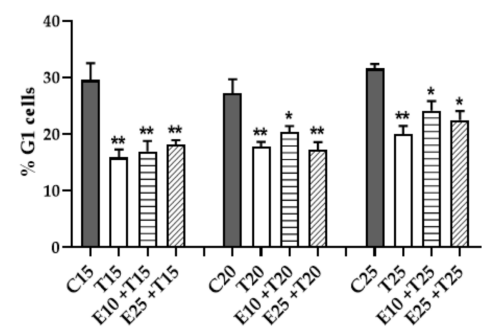

(a)

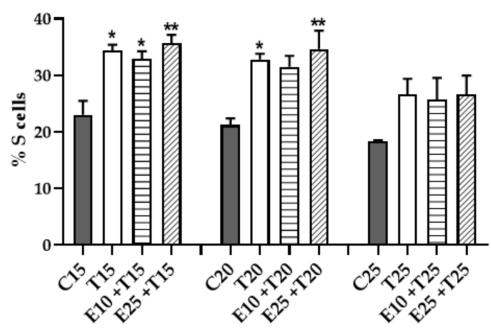

(b)

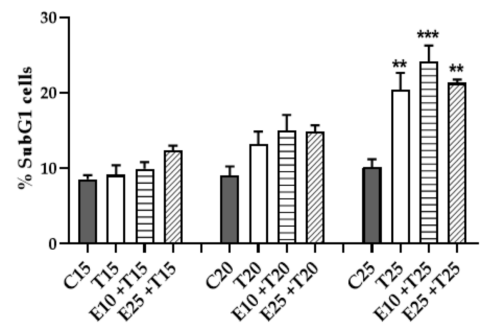

(c)

Figure 9. Flow cytometry cell cycle analysis after Rhus coriaria and UV-A treatment. Cellular population was grouped in five phases, comprising (a) G1 phase, (b) S phase, (c) SubG1 phase. HMEC-1 cells were treated for $1 \mathrm{~h}$ with 10 or $25 \mu \mathrm{g} / \mathrm{mL}$ of $\operatorname{mERC}(\mathrm{E} 10, \mathrm{E} 25)$ and exposed to 15, 20, $25 \mathrm{~J} / \mathrm{cm}^{2} \mathrm{UV}-\mathrm{A}$ (T15, $\mathrm{T} 20, \mathrm{~T} 25)$. Results are expressed as mean $\pm \mathrm{SEM}, n=3$. Statistical analysis: One-Way ANOVA with Bonferroni's post hoc analysis. ${ }^{*} p<0.05^{* *} p<0.01{ }^{* * *} p<0.001$ vs. C PBS.

SubG1 phase (Figure 9c) is index of apoptosis and a significant difference from control samples was observable only at the maximum UV-A dose $\left(25 \mathrm{~J} / \mathrm{cm}^{2}\right)$, where there was a notable increase of the cell's percentage; even in this condition, pre-treatment with mERC gave a similar outcome to UV-only treated samples, increasing the apoptotic population. This result confirmed the previous hypothesis of the apoptotic pathway as a protective strategy against tumor transformation.

\section{Discussion}

Natural polyphenols exert their protective effects acting on various damage pathways; their main beneficial activity is the antioxidant and radical scavenger ability, but also anti-inflammatory and immunomodulatory properties are relevant [18]. Among the botanicals studied in recent literature, Rhus coriaria L. has shown antimicrobial, antiviral, cardioprotective and antihyperglycemic abilities [2] and some extracts displayed also anti-genotoxic features [51].

The ethanolic extract of Rhus coriaria L. used in the present work is particularly rich in phenolic acids, including flavonoids and gallotannins. The extract composition was already reported, and showed a peculiar behavior in reducing inflammation in keratinocytes, indicating a possible application in the treatment of skin disorders [6].

Knowing the main properties of Rhus coriaria L., it is logical to apply the extract in prevention of skin damages induced by UV-A rays' exposure. Indeed, UV-A radiation is able to reach all the layers of the skin and penetrate to the deep dermis where it interacts with fibroblasts and also with the microvascular endothelium [18,52].

UV-A rays are able to generate a great amount of intracellular free radicals leading to oxidative stress and cellular damage [28,53]; this is a particularly severe condition for endothelial cells, whose high damage to cellular biomolecules leads to endothelial dysfunction [37]. As shown in this study, after UV-A exposure, the endogenous antioxidant activity is lowered, as a result of the high amount 
of ROS generation; the extract pre-treatment decreases the formation of these reactive species, while it seems to preserve the antioxidant enzymes and/or their activity. This antiradical activity of Rhus extracts was also confirmed in other cell lines, as erythrocytes exposed to pro-oxidant agents [54]. The molecular mechanisms underlying the antioxidant effects need further investigation; however, pure compounds occurring in sumac including gallic acid [55], anthocyanins and other polyphenols are Nrf-2 modulators [56]. Moreover, another species of the same genus (Rhus verniciflua Stokes) was shown to induce Nrf-2 activity thus corroborating the hypothesis that Rhus coriaria may modulate this transcription factor [57].

UV-A exposure damages the DNA, as demonstrated in this study by various assays, leading to single or double strand breaks. DNA lesions can be originated directly or not, according to different mechanisms: direct damage is due to the interaction between the radiation and the DNA double helix [58], while the induction of photosensitization reactions leads indirectly to DNA detriment [59]. The literature mainly refers to UV-A as an indirect DNA damage source, because the oxidative stress generated is able to affect the main cellular structures, including DNA [58,60]. Instead, this study demonstrates that UV-A exposure leads to a direct injury of the genetic material through the formation of CPDs that are considered to be mainly responsible for UV-B induced mutagenicity [61]. Moreover, UV-A induced also mis-segregation mechanisms, resulting in micronuclei formation. Rhus coriaria L. pre-treatment blocked the formation of DNA lesions, confirming a genoprotective effect which was investigated, at least in part, in animal and human models [16]. Thus, our findings suggest that Rhus coriaria may exert genoprotective effects against low UV-A exposure through antioxidant-independent mechanisms.

The mode of action of the extract used in the present study needs further investigation; however, our suggestions indicate that the extract retains either antioxidant or radical scavenger ability, which could reduce the indirect damage originated by ROS, or promote the DNA protective capacity. A possible explanation of the extract mode of action is the involvement of a direct filter action against UV-A rays due to the presence of polyphenols which are efficiently up-taken by the cells during the pre-treatment and retained in the cytoplasm before irradiation. Regarding this specific physical photoprotection, it was previously demonstrated that anthocyanins-rich extract from strawberries may protect dermal fibroblasts by UV-A filtration [62].

The production of CPDs implies that UV-A exposure can ultimately lead to tumor transformation. To avoid this dangerous outcome, cells can sense the presence of pyrimidine dimers and induce the arrest of cell cycle [50], as seen at lower UV-A doses, where an intraS phase block occurred to allow the DNA damage repair. Conversely, at the higher UVA dosage tested, the damage resulted was too heavy; in this situation, to avoid tumor proliferation, cells prefer to engage a process that blocks RNA transcription and consequently activates p53 and the apoptotic pathway [63]. Interestingly, Rhus coriaria L. extract displayed two opposite behaviors: is genoprotective in cells exposed to medium UV-A doses, while results pro-apoptotic in highly damaged cells, displayed by the accumulation of cells in subG1 phase. The peculiar effect of Rhus coriaria L. extract in activating the apoptotic machinery was already observed in another study, where the extract showed anticlastogenic properties [51], a feature reported also for other polyphenolic extracts $[49,64,65]$. Polyphenol-rich extracts from Rubus spp. and grapevine (Vitis vinifera L.) exhibit pro-apoptotic effect after UVR exposure in vitro and in vivo, as reported in the literature [66-68]. More studies are needed to clarify the mechanism of apoptosis' induction from the extract pre-treatment along with UV-A induced damage.

\section{Conclusions}

In conclusion, this work highlights the beneficial effects of Rhus coriaria L. as a novel source of phytochemicals with antioxidant and antiproliferative properties, while the anti-inflammatorypotential of the extract is still to be investigated. It is noteworthy that the preventive role on microvascular endothelium, against the damage induced by ultraviolet radiation, was exerted at low concentrations (10-25 $\mu \mathrm{g} / \mathrm{mL})$, enabling future applications as local treatment or as dietary supplement or functional 
food. Knowing the latest technologies in polyphenol vehiculation, a drug delivery approach using nano-carriers [69] for reaching the skin endothelial cells may be useful and worthy of further studies.

Supplementary Materials: The following are available online at http://www.mdpi.com/2076-3921/9/4/292/s1, Table S1: Cellular viability used for normalization of cellular antioxidant activity values, measured through MTT assay. Figure S1: Intracellular ROS presence: (a) C20, (b) T20, (c) E25+T20. Fluorescence microscopy, obj. 100X oil, DAPI staining for cellular nuclei, FITC staining for ROS. Figure S2: Alkaline Comet assay: (a) C20, (b) T20, (c) E25+T20. Fluorescence microscopy, obj. 40X oil, propidium iodide staining. Figure S3: FACS report of cellular population in Annexin V assay. (a) C25, (b) T25, (c) E25+T25. For each image: Q3-1 represents the necrotic population, Q3-2 and Q3-4 represent the apoptotic population, Q3-3 represents the living population.

Author Contributions: M.D., E.S., M.M. and L.M. designed the project; E.N., G.M., S.K. and S.P. performed the experiments. All authors have read and agreed to the published version of the manuscript.

Funding: This research was funded by MIUR Progetto di Eccellenza at DiSFeB.

Conflicts of Interest: The authors declare no conflict of interest.

\section{References}

1. Tapiero, H.; Tew, K.D.; Nguyen Ba, G.; Mathé, G. Polyphenols: Do they play a role in the prevention of human pathologies? Biomed. Pharmacother. 2002, 56, 200-207. [CrossRef]

2. Asgarpanah, J.; Saati, S. An overview of phytochemical and pharmacological properties of Rhus coriaria L. Res. J. Pharmacogn. 2014, 1, 47-54.

3. Behnammanesh, G.; Khalilpour, S.; Majid, A.S.A.; Majid, A.M.S.A. Pharmacological actions and potential neuroprotective effects of Rhus coriaria L. In addition, Echium amoenum L.: A brief review. WebmedCentral Pharmacol. 2015, 6, WMC005008.

4. Abu-reidah, I.M.; Jamous, R.M.; Ali-shtayeh, M.S. Phytochemistry, Pharmacological Properties and Industrial Applications of Rhus coriaria L.(Sumac). Jordan J. Biol. Sci. 2014, 7, 233-244. [CrossRef]

5. Kossah, R.; Nsabimana, C.; Zhang, H.; Chen, W. Optimization of extraction of polyphenols from syrian sumac (Rhus Coriaria L.) and chinese sumac (Rhus Typhina L.) fruit. Res. J. Phytochem. 2010, 4, 146-153. [CrossRef]

6. Khalilpour, S.; Sangiovanni, E.; Piazza, S.; Fumagalli, M.; Beretta, G.; Dell'Agli, M. In vitro evidence of the traditional use of Rhus coriaria L. fruit against skin inflammatory conditions. J. Ethnopharmacol. 2019, 238, 111829. [CrossRef]

7. Shabbir, A. Rhus coriaria Linn, a plant of medicinal, nutritional and industrial importance: A review. J. Anim. Plant Sci. 2012, 22, 505-512.

8. Doğan, A.; Çelik, İ. Healing effects of sumac (Rhus coriaria) in streptozotocin-induced diabetic rats. Pharm. Biol. 2016, 54, 2092-2102. [CrossRef]

9. Shafiei, M.; Nobakht, M.; Moazzam, A.A. Lipid-lowering effect of Rhus coriaria L. (sumac) fruit extract in hypercholesterolemic rats. Pharmazie 2011, 66, 988-992.

10. Asgary, S.; Salehizadeh, L.; Keshvari, M.; Taheri, M.; Spence, N.D.; Farvid, M.S.; Rafieian-Kopaei, M.; Sarrafzadegan, N. Potential cardioprotective effects of sumac capsule in patients with hyperlipidemia: A triple-blind randomized, placebo-controlled crossover trial. J. Am. Coll. Nutr. 2018, 37, 286-292. [CrossRef]

11. Sakhr, K.; El Khatib, S. Physiochemical properties and medicinal, nutritional and industrial applications of Lebanese Sumac (Syrian Sumac-Rhus coriaria): A review. Heliyon 2020, 6, e03207. [CrossRef] [PubMed]

12. Isik, S.; Tayman, C.; Cakir, U.; Koyuncu, I.; Taskin Turkmenoglu, T.; Cakir, E. Sumac (Rhus coriaria) for the prevention and treatment of necrotizing enterocolitis. J. Food Biochem. 2019, 43, e13068. [CrossRef] [PubMed]

13. Khalilpour, S.; Behnammanesh, G.; Suede, F.; Ezzat, M.; Muniandy, J.; Tabana, Y.; Ahamed, M.; Tamayol, A.; Majid, A.; Sangiovanni, E.; et al. Neuroprotective and anti-inflammatory effects of rhus coriaria extract in a mouse model of ischemic optic neuropathy. Biomedicines 2018, 6, 48. [CrossRef] [PubMed]

14. Khalilpour, S.; Latifi, S.; Behnammanesh, G.; Majid, A.M.S.A.; Majid, A.S.A.; Tamayol, A. Ischemic optic neuropathy as a model of neurodegenerative disorder: A review of pathogenic mechanism of axonal degeneration and the role of neuroprotection. J. Neurol. Sci. 2017, 375, 430-441. [CrossRef] [PubMed]

15. Khalilpour, S.; Behnammanesh, G.; Abdul Majid, A.M.S.; Tamayol, A.; Abdul Majid, A.S. Assessment of neuroprotective properties of Rhus coriaria L. ethanol extract in an in vitro model of retinal degeneration. J. Herb. Med. 2017, 10, 45-52. [CrossRef] 
16. Chakraborty, A.; Ferk, F.; Simić, T.; Brantner, A.; Dušinská, M.; Kundi, M.; Hoelzl, C.; Nersesyan, A.; Knasmüller, S. DNA-protective effects of sumach (Rhus coriaria L.), a common spice: Results of human and animal studies. Mutat. Res.-Fundam. Mol. Mech. Mutagen. 2009, 661, 10-17. [CrossRef]

17. Heinrich, U.; Moore, C.E.; De Spirt, S.; Tronnier, H.; Stahl, W. Green tea polyphenols provide photoprotection, increase microcirculation, and modulate skin properties of women. J. Nutr. 2011, 141, 1202-1208. [CrossRef]

18. Nichols, J.A.; Katiyar, S.K. Skin photoprotection by natural polyphenols: Anti-inflammatory, antioxidant and DNA repair mechanisms. Arch. Dermatol. Res. 2010, 302, 71-83. [CrossRef]

19. Afaq, F.; K Katiyar, S. Polyphenols: Skin photoprotection and inhibition of photocarcinogenesis. Mini-Rev. Med. Chem. 2012, 11, 1200-1215.

20. Dunaway, S.; Odin, R.; Zhou, L.; Ji, L.; Zhang, Y.; Kadekaro, A.L. Natural antioxidants: Multiple mechanisms to protect skin from solar radiation. Front. Pharmacol. 2018, 9, 392. [CrossRef]

21. Battie, C.; Jitsukawa, S.; Bernerd, F.; Del Bino, S.; Marionnet, C.; Verschoore, M. New insights in photoaging, UVA induced damage and skin types. Exp. Dermatol. 2014, 23, 7-12. [CrossRef] [PubMed]

22. Metral, E.; Rachidi, W.; Damour, O.; Demarne, F.; Bechetoille, N. Long-term genoprotection effect of sechium edule fruit extract against UVA irradiation in keratinocytes. Photochem. Photobiol. 2018, 94, 343-350. [CrossRef] [PubMed]

23. Jansen, R.; Osterwalder, U.; Wang, S.Q.; Burnett, M.; Lim, H.W. Photoprotection: Part II. Sunscreen: Development, efficacy, and controversies. J. Am. Acad. Dermatol. 2013, 69, 867-e1. [CrossRef] [PubMed]

24. Komatsu, T.; Sasaki, S.; Manabe, Y.; Hirata, T.; Sugawara, T. Preventive effect of dietary astaxanthin on UVA-induced skin photoaging in hairless mice. PLoS ONE 2017, 12, 171-178. [CrossRef]

25. Cauchard, J.H.; Robinet, A.; Poitevin, S.; Bobichon, H.; Maziere, J.C.; Bellon, G.; Hornebeck, W. UVA-mediated down-regulation of MMP-2 and MT1-MMP coincides with impaired angiogenic phenotype of human dermal endothelial cells. Biochem. Biophys. Res. Commun. 2006, 345, 681-687. [CrossRef]

26. Seite, S.; Zucchi, H.; Septier, D.; Igondjo-Tchen, S.; Senni, K.; Godeau, G. Elastin changes during chronological and photo-ageing: The important role of lysozyme. J. Eur. Acad. Dermatol. Venereol. 2006, 30, 980-987. [CrossRef]

27. Hern, S.; Mortimer, P.S. Visualization of dermal blood vessels-capillaroscopy. Clin. Exp. Dermatol. 1999, 24, 473-478. [CrossRef]

28. Zheng, P.; Kligman, L.H. UVA-induced ultrastructural changes in hairless mouse skin: A comparison to UVB-induced damage. J. Investig. Dermatol. 1993, 100, 194-199. [CrossRef]

29. D'Alessandro, S.; Magnavacca, A.; Perego, F.; Fumagalli, M.; Sangiovanni, E.; Prato, M.; Dell'Agli, M.; Basilico, N. Effect of hypoxia on gene expression in cell populations involved in wound healing. BioMed Res. Int. 2019, 2019, 2626374. [CrossRef]

30. Heckmann, M.; Eberlein-Konig, B.; Wollenberg, A.; Przbylla, B.; Plewig, G. Ultraviolet-A radiation induces adhesion molecule expression on human dermal microvascular endothelial cells. Br. J. Dermatol. 1994, 131, 311-318. [CrossRef]

31. Meroni, E.; Criscuoli, F.; Casiraghi, M.C.; Erba, D.; Papini, N.; Massaccesi, L.; Basilico, N. Metabolic responses in endothelial cells following exposure to ketone bodies. Nutrients 2018, 10, 250. [CrossRef] [PubMed]

32. Yohn, J.J.; Lyons, M.B.; Norris, D.A. Cultured human melanocytes from black and white donors have different sunlight and ultraviolet a radiation sensitivities. J. Investig. Dermatol. 1992, 99, 454-459. [CrossRef] [PubMed]

33. Lowry, O.; Rosebrough, N.; Farr, L.; Randall, R. Lowry protein assay. J. Biol. Chem. 1951, 193, 365-375.

34. Muthusamy, G.; Balupillai, A.; Govindasamy, K.; Ramasamy, K.; Ponniresan, V.; Malla, I.; Nagarajan, R. Modified comet assays for the detection of cyclobutane pyrimidine dimers and oxidative base damages. J. Radiat. Cancer Res. 2017, 8, 82-86.

35. Fenech, M. The in vitro micronucleus technique. Mutat. Res.-Fundam. Mol. Mech. Mutagen. 2000, 455, 81-95. [CrossRef]

36. Schuch, A.P.; Moreno, N.C.; Schuch, N.J.; Menck, C.F.M.; Garcia, C.C.M. Sunlight damage to cellular DNA: Focus on oxidatively generated lesions. Free Radic. Biol. Med. 2017, 107, 110-124. [CrossRef] [PubMed]

37. Cai, H.; Harrison, D.G. Endothelial dysfunction in cardiovascular diseases: The role of oxidant stress. Circ. Res. 2000, 87, 840-844. [CrossRef]

38. Truong, V.L.; Jun, M.; Jeong, W.S. Role of resveratrol in regulation of cellular defense systems against oxidative stress. BioFactors 2018, 44, 36-49. [CrossRef] 
39. Kosar, M.; Bozan, B.; Temelli, F.; Baser, K.H.C. Antioxidant activity and phenolic composition of sumac (Rhus coriaria L.) extracts. Food Chem. 2007, 103, 952-959. [CrossRef]

40. Pourahmad, J.; Eskandari, M.R.; Shakibaei, R.; Kamalinejad, M. A search for hepatoprotective activity of aqueous extract of Rhus coriaria L. against oxidative stress cytotoxicity. Food Chem. Toxicol. 2010, 48, 854-858. [CrossRef]

41. Segerbäck, D.; Strozyk, M.; Snellman, E.; Hemminki, K. Repair of UV dimers in skin DNA of patients with basal cell carcinoma. Cancer Epidemiol. Biomark. Prev. 2008, 17, 2388-2392. [CrossRef] [PubMed]

42. Shokrollahi Barough, M.; Hasanzadeh, H.; Barati, M.; Pak, F.; Kokhaei, P.; Rezaei-Tavirani, M. Apoptosis/necrosis induction by ultraviolet, in ER positive and ER negative breast cancer cell lines. Int. J. Cancer Manag. 2015, 8, 41-93. [CrossRef] [PubMed]

43. Wischermann, K.; Popp, S.; Moshir, S.; Scharfetter-Kochanek, K.; Wlaschek, M.; De Gruijl, F.; Hartschuh, W.; Greinert, R.; Volkmer, B.; Faust, A.; et al. UVA radiation causes DNA strand breaks, chromosomal aberrations and tumorigenic transformation in HaCaT skin keratinocytes. Oncogene 2008, 27, 4269-4280. [CrossRef] [PubMed]

44. Luzhna, L.; Kathiria, P.; Kovalchuk, O. Micronuclei in genotoxicity assessment: From genetics to epigenetics and beyond. Front. Genet. 2013, 4, 131. [CrossRef] [PubMed]

45. Cadet, J.; Douki, T. Formation of UV-induced DNA damage contributing to skin cancer development. Photochem. Photobiol. Sci. 2018, 17, 1016-1841. [CrossRef] [PubMed]

46. Mouret, S.; Philippe, C.; Gracia-Chantegrel, J.; Banyasz, A.; Karpati, S.; Markovitsi, D.; Douki, T. UVA-induced cyclobutane pyrimidine dimers in DNA: A direct photochemical mechanism? Org. Biomol. Chem. 2010, 8, 1706-1711. [CrossRef]

47. Mouret, S.; Baudouin, C.; Charveron, M.; Favier, A.; Cadet, J.; Douki, T. Cyclobutane pyrimidine dimers are predominant DNA lesions in whole human skin exposed to UVA radiation. Proc. Natl. Acad. Sci. USA 2006, 103, 13765-13770. [CrossRef]

48. Delinasios, G.J.; Karbaschi, M.; Cooke, M.S.; Young, A.R. Vitamin E inhibits the UVAI induction of "light" and "dark" cyclobutane pyrimidine dimers, and oxidatively generated DNA damage, in keratinocytes. Sci. Rep. 2018, 8, 423. [CrossRef]

49. Gong, C.; Yang, Z.; Zhang, L.; Wang, Y.; Gong, W.; Liu, Y. Quercetin suppresses DNA double-strand break repair and enhances the radiosensitivity of human ovarian cancer cells via p53-dependent endoplasmic reticulum stress pathway. OncoTargets. Ther. 2018, 11, 17-27. [CrossRef]

50. Lo, H.L.; Nakajima, S.; Ma, L.; Walter, B.; Yasui, A.; Ethell, D.; Owen, L.B. Differential biologic effects of CPD and 6-4PP UV-induced DNA damage on the induction of apoptosis and cell-cycle arrest. BMC Cancer 2005, 5, 135. [CrossRef]

51. Timocin, T.; Arslan, M.; Basri Ila, H. Evaluation of in vitro and in vivo genotoxic and antigenotoxic effects of Rhus coriaria. Drug Chem. Toxicol. 2019, 1-9. [CrossRef] [PubMed]

52. Svobodová, A.; Psotová, J.; Walterová, D. Natural phenolics in the prevention of UV-induced skin damage. A review. Biomed. Pap. Med. Fac. Univ. Palacky. Olomouc. Czech Repub. 2003, 147, 137-145. [CrossRef] [PubMed]

53. Masaki, H. Role of antioxidants in the skin: Anti-aging effects. J. Dermatol. Sci. 2010, 58, 85-90. [CrossRef] [PubMed]

54. Olchowik, E.; Sciepuk, A.; Mavlyanov, S.; Abdullajanova, N.; Zamaraeva, M. Antioxidant capacities of polyphenols from Sumac (Rhus typhina L.) leaves in protection of erythrocytes against oxidative damage. Biomed. Prev. Nutr. 2012, 2, 99-105. [CrossRef]

55. Pandurangan, A.K.; Mohebali, N.; Norhaizan, M.E.; Looi, C.Y. Gallic acid attenuates dextran sulfate sodium-induced experimental colitis in balb/c mice. Drug Des. Dev. Ther. 2015, 9, 3923-3934. [CrossRef] [PubMed]

56. Boo, Y.C. Can plant phenolic compounds protect the skin from airborne particulate matter? Antioxidants 2019, 8, 379. [CrossRef]

57. Choi, D.R.; Jeong, J.H.; Yu, K.S.; Lee, N.S.; Jeong, Y.G.; Kim, D.K.; Na, C.S.; Na, D.S.; Hwang, W.M.; Han, S.Y. Extract of rhus verniciflua stokes protects against renal ischemia-reperfusion injury by enhancing nrf2-mediated induction of antioxidant enzymes. Exp. Ther. Med. 2018, 15, 3827-3835. [CrossRef]

58. Douki, T.; Sage, E. Dewar valence isomers, the third type of environmentally relevant DNA photoproducts induced by solar radiation. Photochem. Photobiol. Sci. 2016, 15, 24-30. [CrossRef] 
59. Wondrak, G.T.; Jacobson, M.K.; Jacobson, E.L. Endogenous UVA-photosensitizers: Mediators of skin photodamage and novel targets for skin photoprotection. Photochem. Photobiol. Sci. 2006, 5, 215-237. [CrossRef]

60. Pouget, J.P.; Douki, T.; Richard, M.J.; Cadet, J. DNA damage induced in cells by $\gamma$ and UVA radiation as measured by HPLC/GC-MS and HPLC-EC and comet assay. Chem. Res. Toxicol. 2000, 13, 541-549. [CrossRef]

61. Brash, D.E.; Rudolph, J.A.; Simon, J.A.; Lin, A.; Mckenna, G.J.; Baden, H.P.; Halperin, A.J.; Pontén, J. A role for sunlight in skin cancer: UV-induced p53 mutations in squamous cell carcinoma. Proc. Natl. Acad. Sci. USA 1991, 88, 10124-10128. [CrossRef] [PubMed]

62. Gasparrini, M.; Forbes-Hernandez, T.Y.; Afrin, S.; Reboredo-Rodriguez, P.; Cianciosi, D.; Mezzetti, B.; Quiles, J.L.; Bompadre, S.; Battino, M.; Giampieri, F. Strawberry-based cosmetic formulations protect human dermal fibroblasts against UVA-induced damage. Nutrients 2017, 9, 605. [CrossRef] [PubMed]

63. Batista, L.F.Z.; Kaina, B.; Meneghini, R.; Menck, C.F.M. How DNA lesions are turned into powerful killing structures: Insights from UV-induced apoptosis. Mutat. Res.-Rev. Mutat. Res. 2009, 681, 197-208. [CrossRef]

64. D’Angleo, S.; Martino, E.; Ilisso, C.P.; Bagarolo, M.L.; Porcelli, M.; Cacciapuoti, G. Pro-oxidant and pro-apoptotic activity of polyphenol extract from Annurca apple and its underlying mechanisms in human breast cancer cells. Int. J. Oncol. 2017, 51, 939-948.

65. Armentano, M.F.; Bisaccia, F.; Miglionico, R.; Russo, D.; Nolfi, N.; Carmosino, M.; Andrade, P.B.; Valentão, P.; Diop, M.S.; Milella, L. Antioxidant and proapoptotic activities of sclerocarya birrea [(A. Rich.) Hochst.] methanolic root extract on the hepatocellular carcinoma cell line HepG2. BioMed Res. Int. 2015, 2015, 561589. [CrossRef] [PubMed]

66. Duncan, F.J.; Martin, J.R.; Wulff, B.C.; Stoner, G.D.; Tober, K.L.; Oberyszyn, T.M.; Kusewitt, D.F.; Van Buskirk, A.M. Topical treatment with black raspberry extract reduces cutaneous UVB-induced carcinogenesis and inflammation. Cancer Prev. Res. 2009, 2, 665-672. [CrossRef] [PubMed]

67. Calvo-Castro, L.; Syed, D.N.; Chamcheu, J.C.; Vilela, F.M.P.; Pérez, A.M.; Vaillant, F.; Rojas, M.; Mukhtar, H. Protective effect of tropical highland blackberry juice (Rubus adenotrichos Schltdl.) against UVB-mediated damage in human epidermal keratinocytes and in a reconstituted skin equivalent model. Photochem. Photobiol. 2013, 89, 1199-1207. [CrossRef]

68. Marabini, L.; Melzi, G.; Lolli, F.; Dell'Agli, M.; Piazza, S.; Sangiovanni, E.; Marinovich, M. Effects of Vitis vinifera L. leaves extract on UV radiation damage in human keratinocytes (HaCaT). J. Photochem. Photobiol. $B$ Biol. 2020, 204, 111810. [CrossRef]

69. Liu, Y.; Yang, R.; Liu, J.; Meng, D.; Zhou, Z.; Zhang, Y.; Blanchard, C. Fabrication, structure, and function evaluation of the ferritin-based nano-carrier for food bioactive compounds. Food Chem. 2019, 299, 125097. [CrossRef]

(C) 2020 by the authors. Licensee MDPI, Basel, Switzerland. This article is an open access article distributed under the terms and conditions of the Creative Commons Attribution (CC BY) license (http://creativecommons.org/licenses/by/4.0/). 